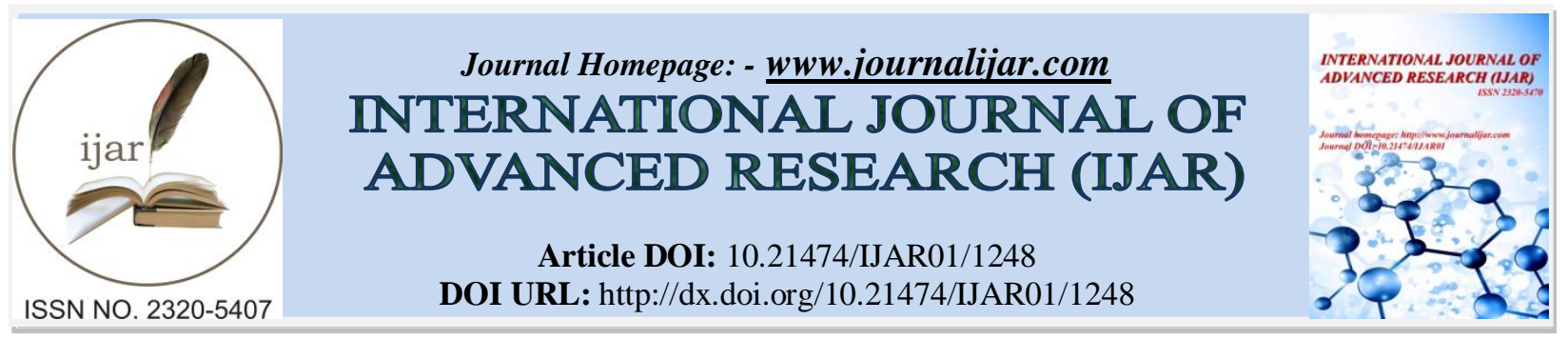

RESEARCH ARTICLE

\title{
A STUDY ON MORPHOMETRIC MEASUREMENTS OF ADULT DRIED FEMORA IN VISAKHAPATNAM.
}

\section{Dr.Neelima $\mathbf{P}^{\mathbf{1}}$,Dr.R.Ravi sunder ${ }^{2}$ and Dr.A.Hima bindu ${ }^{3}$.}

1. Associate Professor, department of Anatomy, GIMSR, Visakhapatnam.

2. Associate Professor, department of Physiology, GIMSR, Visakhapatnam.

3. Professor\& HOD, department of Anatomy, GIMSR, Visakhapatnam.

\section{Manuscript Info}

Manuscript History

Received: 12 June 2016

Final Accepted: 13 July 2016

Published: August 2016

Key words:-

Morphometry, dried femora, length,

shaft, intercondylar notch.

\section{Abstract}

Background:-Femur varies in its morphology and morphometry in relation to geography, race, ethnic groups and gender.

Aims and objectives:-To measure different morphometric parameters on adult dried femora of Visakhapatnam district and compare the same with other studies.

Materials and methods: - 60 dried femora in the department were evaluated for the following measurements. These included length, diameter of shaft at three levels, length and width of neck, anteroposterior length and width of condyles, height and width of intercondylar notch. All parameters were analyzed statistically. The results were compared and represented graphically.

Result: - The mean values for the various parameters were as follows: length of femur was $414.83 \mathrm{~mm}$, the diameter of head was $122.5 \mathrm{~mm}$, length of neck-27.5mm, width of neck-48.33mm, diameter of upper shaft- $81.75 \mathrm{~mm}$, middle-77.75mm and lower shaft-113.83mm. The medial condyle antero-posterior length was $57.83 \mathrm{~mm}$, and width was $21.33 \mathrm{~mm}$. The antero-posterior length of lateral condyle- $58 \mathrm{~mm}$ and width $21.08 \mathrm{~mm}$. The height of intercondylar notch was $22.66 \mathrm{~mm}$ and width $22.83 \mathrm{~mm}$.

Conclusion:-There is a considerable diversity in the direct and indirect studies on femur. This study provides the data of dried femora in Visakhapatnam district.

\section{Introduction:-}

Femur is the longest and strongest bone in the human body ${ }^{1}$. Femur is known for its diversity among different races, ethnic groups and different geographical areas. It is considered as one of the common bones to exhibit sexual dimorphism. These variations clinch the importance of femur in medico legal cases and identification of sex. The neck shaft angle and neck length are variable ${ }^{1}$. The knowledge of morphometry of upper end or shaft or lower end of femur is helpful for designing required prosthesis or internal fixators, to know the anatomical facts for the underlying pathologies and also in surgical implications. Many direct studies ${ }^{(3,4,5 \text {, and } 6)}$ determine the variations in 
morph metric measurements. Indirect studies ${ }^{(10,11 \text {, and } 12)}$ on x-ray, CT, MRI scans or 3D reconstructed models were also performed. The present study was conducted to know the variations in certain parameters on dried femora.

\section{Materials and methods:-}

Dried femora from the department of Anatomy belonging to both genders and both lower limbs formed the material for the study. Femora with deformities, loss of some parts and prosthesis involved bones were discarded. 60 normal femora were evaluated for the study. The length of femur was measured from upper end of femoral head to lower point on the femoral condyle. Maximum diameter of the head of femur was measured. The diameter and length of neck was obtained. The diameter of shaft was taken at upper, middle and lower levels. The antero-posterior length and thickness of two condyles were measured. The width and height of the intercondylar notch was measured by keeping femur in vertical position. The results were tabulated, graphically represented and compared with those of other studies. Statistical analysis was done and p-value was calculated using chi square test and degree of freedom from standard $\mathrm{p}$ value calculator. Chi square was calculated using the following formula

$(\mathrm{O}-\mathrm{E})^{2}$

$$
\mathrm{X}^{2}=\sum \text { E }
$$

Where $\mathrm{X}^{2}$ is chi square; $\mathrm{O}$ is observed value and $\mathrm{E}$ is expected value.

\section{Results:-}

Table 1:- The mean values of various parameters obtained from dried femora.

\begin{tabular}{|l|l|l|l|}
\hline S No. & Parameter measured & Mean in $\mathbf{~ m m})$ & Standard Deviation \\
\hline 1. & Length of femur & 414.83 & 2.945 \\
\hline 2. & Max. diameter of head & 122.5 & 1.270 \\
\hline 3. & Length of neck & 27.5 & 0.634 \\
\hline 4. & Width of neck & 48.33 & 0.876 \\
\hline 5. & Diameter of upper shaft & 81.75 & 0.837 \\
\hline 6. & Diameter of middle shaft & 77.75 & 0.967 \\
\hline 7. & Diameter of lower shaft & 113.83 & 1.270 \\
\hline 8. & Antero-posterior length of medial condyle & 57.83 & 0.697 \\
\hline 9. & Width of medial condyle & 21.33 & 0.430 \\
\hline 10. & Antero-posterior length of lateral condyle & 58 & 0.514 \\
\hline 11. & Width of lateral condyle & 21.08 & 0.442 \\
\hline 12. & Intercondylar notch width & 22.83 & 0.405 \\
\hline 13. & Intercondylar notch height & 22.66 & 0.516 \\
\hline
\end{tabular}


Graph 1:- Bar chart comparing the length of femur from various studies

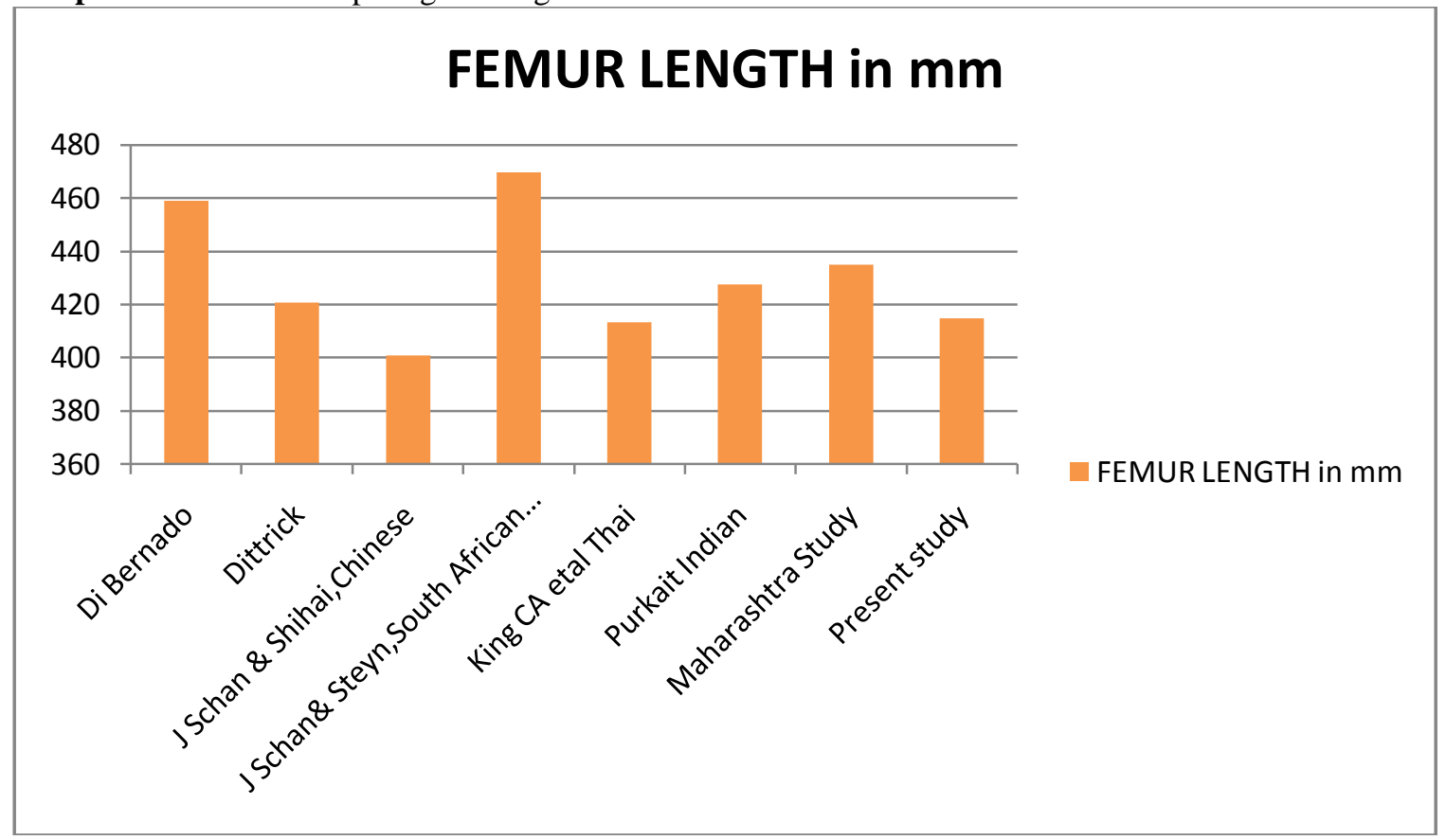

\section{Discussion:-}

Variations are common in different morphometric measurements of femur, causes being multifold. The present study was done to evaluate various measurements on dried femora and to compare with those of other studies.

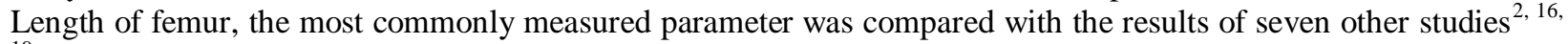

19. The mean length of femur of the present study was $414.83 \mathrm{~mm}$, nearer to the study made by King CA etal, Thai $($ mean $=413.2 \mathrm{~mm})$. $\mathrm{p}$ value was calculated which was not quite statistically significant. Other parameters were also measured and tabulated. The standard deviation from the mean for length of femur was maximum i.e., 2.945 when compared to other measurements indicating a wide variation in the length. Next two parameters i.e., diameter of head \& diameter of lower shaft showed a standard deviation of 1.270 from the mean value determining a considerable variation. Other parameters exhibited a slight deviation from the mean values.

\section{Conclusion:-}

The present study provides the information of measurements of various parameters on dried femora belonging to areas in and around Visakhapatnam. The results were compared with other studies. The length of femur showed gross variations when compared to other parameters.

\section{References:-}

1. Gray's Anatomy the anatomical basis of clinical practice, Susan Standring $40^{\text {th }}$ edition, Churchill Livingstone, pg 1360\&1390.

2. Rajeshwari S. Bhosale, Dr. B. R. Zambare. Sex determination from femur using length of femur in Maharashtra. IOSR Journal of Dental and Medical Sciences (JDMS) ISSN: 2279-0853, ISBN: 2279-0861. Volume 3, Issue 4 (Jan. - Feb. 2013), PP 01-03.

3. Ioannis Terzidis, Trifon Totlis et al.,Gender and Side-to-Side Differences of Femoral Condyles Morphology: Osteometric Data from 360 Caucasian Dried Femora Anatomy Research International Volume 2012 (2012), Article ID 679658, 6 pages

4. B. V. Murlimanju, Latha V. Prabhu et al Osteometric study of the upper end of femur and its clinical applications. European Journal of Orthopaedic Surgery \& Traumatology April 2012, Volume 22, Issue 3, pp 227-230 First online: 04 June 2011.

5. RC Siwach, S Dahiya. Anthropometric study of proximal femur geometry and its clinical application. Indian Journal of Orthopaedics. 2003; 37 (4): 247-51.

6. Christ lavelle. An analysis of human femur 1974 American Journal of Anatomy, 141:3:415-426. 
7. Purkait R. and Chandra H., Sexual Dimorphism in Femora: An Indian Study. Forensic Science Communications 2002 July, 4(3): 1-6.

8. Singh S. P. and Singh S., The sexing of adult femora: Demarking points for Varanasi zone, Journal of the Indian Academy of Forensic Sciences 1972 B, 11:1- 6.

9. W. P. H. Charlton, T. A. S. John, M. G. Ciccotti, N. Harrison, and M. Schweitzer, "Differences in femoral notch anatomy between men and women. A magnetic resonance imaging study," American Journal of Sports Medicine, vol. 30, no. 3, pp. 329-333, 2002.

10. B. Yue, K. M. Varadarajan, S. Ai, T. Tang, H. E. Rubash, and G. Li, "Gender differences in the knees of Chinese population," Knee Surgery, Sports Traumatology, Arthroscopy, vol. 19, no. 1, pp. 80-88, 2011.

11. W. P. H. Charlton, T. A. S. John, M. G. Ciccotti, N. Harrison, and M. Schweitzer, "Differences in femoral notch anatomy between men and women. A magnetic resonance imaging study," American Journal of Sports Medicine, vol. 30, no. 3, pp. 329-333, 2002.

12. F. Yazar, N. Imre, B. Battal, S. Bilgic, and C. Tayfun, "Is there any relation between distal parameters of the femur and its height and width?" Surgical and Radiologic Anatomy, vol. 34, no. 2, pp. 125-132, 2011.

13. J. Dargel, J. Feiser, M. Gotter, D. Pennig, and J. Koebke, "Side differences in the anatomy of human knee joints," Knee Surgery, Sports Traumatology, Arthroscopy, vol. 17, no. 11, pp. 1368-1376, 2009.

14. C. D. Harner, L. E. Paulos, A. E. Greenwald, T. D. Rosenberg, and V. C. Cooley, "Detailed analysis of patients with bilateral anterior cruciate ligament injuries," American Journal of Sports Medicine, vol. 22, no. 1, pp. 3743, 1994.

15. N. K, Shaik HS. Morphometric study of human femur. IJCRR. 2013; 5(6): 76-79.

16. De sousa, E.; Fernandes, R. M. P.; Mathias, M. B.; Rodrigues, M. R.; Ambram, A. J.\& Babinski, M. A. "Morphometric study of the proximal femur extremity in Brazilians". Int. J. Morphol., 28(3):835-840, 2010

17. Shakil Mohamad Khan, Shaik Hussain Saheb. Study on neck shaft angle and femoral length of south Indian femurs. Int J Anat Res 2014; 2(4):633-635. DOI: 10.16965/ ijar.2014.512. 